\title{
Acquisition of Type 1 herpes simplex vulvitis within a monogamous relationship
}

\author{
JANET E. WhitNEY, G. R. B. SKINNER, AND A. BUCHAN \\ From the Department of Medical Microbiology, The Medical School, Birmingham
}

Although Type 1 herpes simplex virus infections of the genitals have been reported (Smith et al., 1973; Chang et al., 1974; Dolin et al., 1976) in women, Type 2 herpes virus is more commonly isolated; in extensive surveys by Dowdle et al. (1967), Plummer et al. (1974), and Skinner et al. (1976) every isolate from the female genital tract was found to be Type 2 . Recognition of the sexual mode of transmission of this condition preceded the 'discovery' of viruses; Greenough (1881) correlated the incidence of the condition in men with a history of other venereal disorders, and Unna (1883) reported that $1 \%$ of prostitutes attending the Hamburg General Hospital had genital herpes. More recently, the sexual transmission of this infection was confirmed by virological follow-up of female consorts of male patients with penile herpes (Nahmias et al., 1969).

In this paper, we report a case of Type 1 herpes virus infection of the vulva which almost certainly was contracted by orogenital contact between marital partners.

\section{Case report}

The patient was a 20 -year-old laboratory technician. She had been married for 11 months with no pregnancies or abortions. Neither the patient nor her husband reported pre-marital or extramarital sexual relations.

Forty-eight hours after oral sex with her husband, the patient became aware of a tender area on the vulva. There was no vaginal discharge although the patient did complain of superficial dysuria which was not accompanied by frequency or urgency of micturition. There was no upset or irregularity of menstrual function. She did not give a history of recurrent cold sores on the lips.

The patient's husband reported that he had a cold sore on his lips 48 hours before the episode of

\footnotetext{
Address for reprints: G. R. B. Skinner, Department of Medical Microbiology, The Medical School, Birmingham B15 2TJ

Received for publication 12 August 1977
}

oral sex. There was no evidence of digital or penile herpes infection.

Examination revealed three tender ulcers around the clitoris. There were no other genital abnormalities.

A presumptive clinical diagnosis of herpetic vulvitis was made and the appropriate laboratory specimens for virological investigation were taken. The patient was advised to avoid touching the lesions and to abstain from sexual intercourse. Iodoxuridine $(5 \mathrm{~g} / 100 \mathrm{ml}$ of dimethylsulphoxide-DMSO), was applied to the lesions and the patient asked to continue treatment thrice daily for three days. Within five to six days the lesions had almost resolved and the tenderness had disappeared by the eighth day from onset.

\section{VIROLOGICAL INVESTIGATIONS}

Herpes simplex virus was isolated in BHK-21 cells (MacPherson and Stoker, 1962) as previously described (Skinner, 1976). The virus was shown to be Type 1 herpes simplex virus by its behaviour in reciprocal cross-neutralisation and immunodiffusion tests with Type 1 and Type 2 antiserum raised in rabbits (Thouless, 1972; Skinner et al., 1976), and by the stability of its enzyme - thymidine kinase (Thouless and Skinner, 1971) (Table 1). The validity of these various criteria for virus typing has been discussed (Plummer et al., 1974). Unfortunately, we were unable to isolate virus from the healing lesions on the husband's lips, probably because he was seen too late in the course of his infection.

Serum complement-fixing antibody activity against both types of viral antigen was found within three weeks from the onset of the lesions and reached a peak within about seven weeks of the original lesion. There was, however, demonstrable complement-fixing activity still present within one year of the clinical lesion (Table 2). There was an unusually low serum neutralising antibody activity against both virus types for 10 months after the appearance of the clinical lesion when the serum 
Table 1 Evidence that clinical isolate was a Type 1 herpes simplex virus

\begin{tabular}{|c|c|c|c|c|c|}
\hline & \multicolumn{3}{|c|}{ Neutralisation $\dagger$ rate constants $(k$-value) } & \multirow{2}{*}{$\begin{array}{l}\text { Immunodiffusion } \\
\text { pattern }\end{array}$} & \multirow{2}{*}{$\begin{array}{l}\text { Stability of } \ddagger \\
\text { thymidine kinase }\end{array}$} \\
\hline & Type 1 antisera & Type 2 antisera & Ratio Type 1:2 & & \\
\hline $\begin{array}{l}\text { Isolate from patient } \\
\text { Prototypes }\end{array}$ & $3 \cdot 4$ & $1 \cdot 8$ & $1 \cdot 8$ & Type 1 & 85 \\
\hline $\begin{array}{l}\text { Type } 1 \text { strain 'HFEM'* } \\
\text { Type } 2 \text { strain ' } 25766 \text { '* }\end{array}$ & $\begin{array}{l}3 \cdot 1 \\
0 \cdot 5\end{array}$ & $\begin{array}{l}2 \cdot 0 \\
1 \cdot 5\end{array}$ & $\begin{array}{l}1 \cdot 6 \\
0 \cdot 3\end{array}$ & $\begin{array}{l}\text { Type } 1 \\
\text { Type } 2\end{array}$ & $\begin{array}{l}92 \\
40\end{array}$ \\
\hline
\end{tabular}

*The provenance and prototype of these strains has been previously established (Skinner et al., 1976)

†K-values were obtained and calculated as previously described (Skinner et al., 1976)

$\ddagger$ Percentage residual thymidine kinase activity after 15 min at $40^{\circ} \mathrm{C}$

specimen was found to have a Type $1 \mathrm{k}$-value of 0.58 and a Type 2 value of 0.22 , which was consistent with previous infection by Type 1 herpes simplex. The patient's cervical cytology was negative at all times.

The serum of the patient's husband had a neutralising antibody activity of 1.8 against Type 1 and $\mathbf{0} .33$ against Type 2 . This also suggested a history of Type 1 virus infection.

The patient was followed-up at regular intervals for a year. There was no further evidence of clinical disease, herpes virus was not isolated, and the cervical cytology remained negative.

Fifteen months after the primary infection, the patient reported a further episode of vulval tenderness. Extramarital sexual relations had not occurred and, while normal marital sexual intercourse had taken place once or twice a week, the last orogenital contact had been several months before. The patient did report being rather 'run-down' after a recent severe bout of influenza.

Examination revealed four typical herpetic lesions around the clitoris. The lesions were smaller than during the previous clinical episode-about 2 to 4 $\mathrm{mm}$-and seemed rather less tender to palpation. No other gynaecological abnormality was apparent.

The patient was treated as before (vide supra). On this occasion the lesions completely disappeared four days after their onset.

Type 1 herpes simplex virus was again isolated.
The serum neutralising and complement-fixing antibody activity rose (Table 2), again suggesting previous Type 1 herpes virus infection. The latest specimen, obtained 10 days after recurrence of the clinical lesion (Table 2), demonstrated a common immunoprecipitating antibody between Type 1 and Type 2 herpes simplex virus.

\section{Discussion}

A case of primary and recurrent Type 1 herpetic vulvitis has been described. Two important features emerge:

The history of oral sex with a male partner suffering from a labial herpetic lesion, together with the unequivocal laboratory evidence that the aetiological agent at primary presentation and at recurrence was herpes simplex virus Type 1 indicates that herpetic vulvitis is not an exclusively genital-togenital 'venereal disease' and can occur within the framework of a monogamous relationship. The case is not, of course, proved but it might discourage excess contact inquiries in other cases. The value of virus isolation and typing is apparent.

A second point of interest concerns the feeble delayed primary neutralising antibody response in this patient. We also observed this phenomenon on two other patients who had exclusively introital lesions which were of limited extent and duration,

Table 2 Serological reactivity from date of primary infection

\begin{tabular}{|c|c|c|c|c|}
\hline \multirow[b]{2}{*}{ Date } & \multicolumn{2}{|c|}{ Neutralisation rate constants ( $k$-value) } & \multicolumn{2}{|c|}{ Reciprocal complement-fixation titre against viral antigen } \\
\hline & Type 1 virus & Type 2 virus & Type 1 & Type 2 \\
\hline $\begin{array}{l}12.12 .75 \\
15.12 .76 \\
5.1 .76 \\
12.2 .76 \\
7.7 .76 \\
27.10 .76 \\
6.3 .77 \\
10.3 .77\end{array}$ & $\begin{array}{l}\text { Primary episo } \\
0.0 \\
0.02 \\
0.07 \\
0.06 \\
0.58 \\
\text { Recurrence o. } \\
1 \cdot 14\end{array}$ & $\begin{array}{l}\text { vulvitis } \\
0.0 \\
0.0 \\
0.06 \\
0.04 \\
0.22 \\
\text { tis } \\
0.15\end{array}$ & $\begin{array}{l}<25 \\
50 \\
200 \\
100 \\
100 \\
<50 \\
200\end{array}$ & $\begin{array}{r}<25 \\
<25 \\
<50 \\
<50 \\
50 \\
<50 \\
50\end{array}$ \\
\hline 16.3.77 & 1.02 & $0 \cdot 17$ & 100 & 50 \\
\hline
\end{tabular}

K-values and complement-fixing titres were obtained and calculated as previously described (Skinner et al., 1976)

Complement-fixing titres of sera 12.12 .75 and $\mathbf{1 5 . 1 2 . 7 5}$ were obtained with different antigen preparations than were used with the other sera 
and it may be that the feeble neutralising antibody response is related to an inadequate dose of priming antigen. This is consistent with the observations of Birch et al. (1976) who reported that Type 1 herpes virus grew less well and produced less antigen in cervical organ culture. The neutralising antibody activity did, however, significantly increase between July and October 1976 and must be presumed to be a result of a 'subclinical recurrence' of infection during that period of time.

Recurrence of herpes genitalis is a difficult therapeutic problem but seems to respond in some measure to 'persistent' iodoxuridine therapy (JuelJensen and MacCallum, 1972). In our case, the absence of extramarital contact, the identical distribution of the herpetic lesions on recurrence and the reisolation of Type 1 herpes simplex virus from the lesions is strong evidence in favour of a recurrence from a latent virus infection rather than an exogenous reinfection. This poses future problems in management, particularly towards avoiding the establishment of penile herpes infection in the husband and, of course, in a possible fetus. On this account, the patient has been advised to report immediately any further symptoms and abstain from sexual intercourse until the lesions appear or until positive viral isolations have been made. In this event it is intended to resume iodoxuridine treatment.
References

Birch, J., Fink, C. G., Skinner, G. R. B., Thomas, G. H., and Jordan, J. A. (1976). Replication of Type 2 herpes simplex virus in human endocervical tissue in organ culture. British Journal of Experimental Pathology, 57, 460-471.

Chang, T. W., Fiumara, N. J., and Weinstein, L. (1974). Genital herpes-some clinical and laboratory observations. Journal of the American Medical Association, 229, 544-545.

Dolin, R., Gill, F. A., and Nahmias, A. J. (1976). Genital herpes simplex virus Type 1 infection-variability in modes of spread. Journal of the American Venereal Association, 2, 6-13.

Dowdle, W., Nahmias, A. J., Harwell, R. W., and Pauls, F. (1967). Association of antigenic type of Herpesvirus hominis with site of viral recovery. Journal of Immunology, 99, 974-980.

Greenough, F. B. (1881). Herpes progenitalis. Archives of Dermatology (New York), 7, 67 (discussion).

Juel-Jensen, B. E., and MacCallum, F. O. (1972). Herpes Simplex, Varicella, and Zoster-Clinical Manifestations and Treatment. Heinemann: London.

MacPherson, I., and Stoker, M. (1962). Polyoma transformation of hamster cell clones-an investigation of genetic factors affecting cell competence. Virology, 16, 147-151.

Nahmias, A. J., Dowdle, W. R., Naib, Z. M., Josey, W. E., McLone, D., and Domescik, G. (1969). Genital infection with Type 2 Herpesvirus hominis. British Journal of Venereal Diseases, 45, 294-298.

Plummer, G., Goodheart, C. R., Miyagi, M., Skinner, G. R. B., Thouless, M. E., and Wildy, P. (1974). Herpes simplex viruses: discrimination of types and correlation between different characteristics. Virology, 60, 206-216.

Skinner, G. R. B. (1976). Virus infections of the female genital tract. In The Cervix in Health and Disease, p. 269. Edited by J. A. Jordan and A. Singer. Saunders: London.

Skinner, G. R. B., Thouless, M. E., Trueman, S., and Edwards, J. (1976). Serological relatedness of herpes simplex viruses. Typespecificity of antibody response. Immunology, 31, 481-494.

Smith, I. W., Peutherer, J. F., and Robertson, D. H. H. (1973). Characterisation of genital strains of Herpesvirus hominis. British Journal of Venereal Diseases, 49, 385-390.

Thouless, M. E. (1972). Cited by P. Wildy in Herpesvirus and antigens. In Oncogenesis and Herpesviruses, p. 409. Edited by P. M. Biggs, G. de Thé, and N. L. Payne. International Agency for Research on Cancer: Lyon.

Thouless, M. E., and Skinner, G. R. B. (1971). Differences in the properties of thymidine kinase produced in cells infected with Type 1 and Type 2 herpes virus. Journal of General Virology, 12, 195-197.

Unna, P. G. (1883). On herpes progenitalis, especially in women. Journal of Cutaneous Venereal Diseases, 1, 321-334. 